\title{
Nutritional and Unhealthy Behaviors in Women With and Without Breast Cancer
}

\author{
Maryam Ataollahi $^{1,2}$; Sedigheh Sedighi ${ }^{2, *}$; Seyyedeh Zahra Masoumi ${ }^{3}$ \\ ${ }^{1}$ Department of Midwifery, Faculty of Nursing and Midwifery, Hamadan University of Medical Sciences, Hamadan, IR Iran \\ ${ }_{2}^{2}$ Department of Midwifery, Faculty of Nursing and Midwifery, Shahid Beheshti University of Medical Sciences, Tehran, IR Iran \\ ${ }^{3}$ Mother and Child Care Research Center, Hamadan University of Medical Sciences, Hamadan, IR Iran \\ ${ }^{*}$ Corresponding Author: Sedigheh Sedighi, Department of Midwifery, Faculty of Nursing and Midwifery, Shahid Beheshti University of Medical Sciences, Tehran, IR Iran. Tel: +98- \\ 9128499824. Fax:+98-2188202512, E-mail: sedigehsedigi@ymail.com
}

Received: May 30, 2014; Revised: July 9, 2014; Accepted: August 3, 2014

\begin{abstract}
Background: Breast cancer is the most common malignancy in women. Global statistics indicate increasing rates of this cancer. Nutrition, diet, and healthy behaviors are among influential factors in prevalence of breast cancer, and possibly affect its incidence through inflammatory and immune system responses.

Objectives: This study was designed to compare nutritional and unhealthy behaviors in women with and without breast cancer referred to Mahdieh Imaging Center in Hamadan in 2013.

Patients and Methods: This cross-sectional study is conducted on 232 women with $\mathrm{r}$ and without breast cancer referred to Mahdieh Imaging Center of Hamadan, Iran) in 2013 using random sampling method. Data were collected using nutritional and unhealthybehaviors questionnaires, and analyzed with SPSS-17 software using descriptive statistics and Mann-Whitney, independent t, and chi-square tests. Results: The mean scores of feeding type in the patients with and without breast cancer was 56.14 and 66.25, respectively. Results obtained from data analysis showed that there was statistically significant difference between the two groups in terms of nutrition $(\mathrm{P}<0.001)$, but no relationship was observed between breast cancer and unhealthy behaviors.

Conclusions: Given the results, improving skills, training and awareness is necessary for women and emphasis on modified diet is recommended as a non-medical option for prevention of breast cancer.
\end{abstract}

Keywords:Breast cancer; Nutrition; Lifestyle

\section{Background}

Breast cancer $(\mathrm{BC})$ is the most common malignancy $(1$, 2 ) and the second leading cause of cancer-related mortality in women (3). Global statistics indicate increasing rate of $\mathrm{BC}$ incidence, especially in developing countries (4). Although BC is one of the most common cancers in women, its prevalence widely varies in different parts of the world, which could be due to differences in lifestyles, such as nutrition and unhealthy behaviors, reproductive history, or genetic history (4-7). According to estimates, there are 180,000 new cases of BC in the United States every year (8). Also, of every three women with cancer, one has BC (1). In Iran, the prevalence of BC is 1\% (9). Although the incidence of breast cancer is still low comparing with Western countries (Iran, 23.65 per 100000 and United States, 140.8 per 100000 Caucasian women) (10), new statistics indicate increasing rates of new BC cases (11). Results of several studies indicate that genes are not the main source of chronic diseases such as BC; for instance, a study conducted on identical twins shows that the effect of genes on BC is only $20 \%(12)$, while the effect of lifestyle and environmental factors in causing chronic diseases including BC is $90-95 \%$ (13). Risk factors associated with $\mathrm{BC}$ can be divided into two groups: risk factors that can be modified, and risk factors that cannot. Nutrition, smoking and alcohol use are among risk factors that can be modified. Because of vast differences in breast cancer in different areas, diet is considered one of the causes of breast cancer $(7,14,15)$. Changing growth factors, such as insulin, may increase the risk of BC (16). There is evidence that cancer is a preventable disease, and requires quitting smoking, restricting alcohol use, increasing intake of fruits and vegetables, limiting calorie intake, exercise, avoiding exposure to direct sunlight, minimizing red meat consumption, use of whole grains, vaccination, and frequent follow-ups $(17,18)$.

Moreover, according to studies, compliance with the above-mentioned can lead to longer survival of breast cancer patients (12). According to researches, there is an inverse relationship between use of liquid oils with high levels of poly-unsaturated fatty acids (PUFA) n-3 such as olive oil and BC. However, use of animal fat increases the risk of $B C(19,20)$. The Alcohol increases serum estrogen level and disrupts metabolism and absorption of folate, which increases risk of $\mathrm{BC}(16,21,22)$. One of the objec-

Copyright (C) 2014, Iranian Red Crescent Medical Journal; Published by Kowsar. This is an open-access article distributed under the terms of the Creative Commons Attribution-NonCommercial 4.0 International License (http://creativecommons.org/licenses/by-nc/4.0/) which permits copy and redistribute the material just in noncommercial usages, provided the original work is properly cited. 
tives of the World Health Organization by 2020 is promotion of healthy lifestyle, reduction of factors harmful to people's health, including wrong nutrition and use of alcohol (23).

\section{Objectives}

The prevalence of cancers, particularly breast cancer is increasing, and BC can be prevented through identifying nutritional factors and modifying the diet. There is also a lack of a comprehensive study in this area. Thus, this study is designed to compare nutritional and unhealthy behaviors in women with and without $\mathrm{BC}$ referred to Mahdieh Imaging Center of Hamadan in 2013.

\section{Patients and Methods}

This cross-sectional study was conducted on 116 women with BC and 116 healthy women presenting to Mahdieh Imaging Center of Hamadan (Hamadan, Iran) from October to December 2013. After approval of the study protocol (date 20/7/2013), the permission obtained from the Research Deputy of Shahid Beheshti University of Medical Sciences was presented to the Director of Mahdieh Imaging center of Hamadan. Random sampling method was used, and subjects were selected among breast cancer patients aged 20-60 years, regular menstrual periods, no known medical conditions such as diabetes, thyroid disorders and polycystic ovary syndrome, no hormone replacement therapy and no changes in diet in the past three years. The two groups were matched for variables related to breast cancer including age, weight, body mass index (BMI) and age of menarche. Sample size was estimated of 116 individuals in each group with 95\% confidence interval. Every ethical consideration was observed. Participants were informed about the purpose and methods of the study and the interested women were invited to participate in this study. Furthermore, written informed consents were obtained from these individuals. Pathologically, cancer was confirmed in one point in the breast in women with BC. Individuals without breast cancer - including those referred to Mahdieh Imaging Center for other reasons and there was no known cancer according to self-report were included in our control group. Data collection tools included demographic details, diet, and unhealthy behaviors questionnaires. The researcher-made questionnaire for nutrition includes 28 items. The subjects at first studied the directions to answer the questions, which contained some explanations about different food groups and then answered the researcher's questions. Questions included consumption of fruits, vegetables, meat, cereals, nuts and oilseeds, low-fat dairy, whole-grain bread, fish, the kind of oil including liquid oil, solid or animal fat, fast foods, white sauce, sausages, chicken wings, neck and skin, salty foods, potato chips and snacks, soda drinks, and fried foods. Answers to questions included a "daily", "weekly", "monthly" and "annual" food consumption as well as "never" option. The items about cereals, fruits and vegetables, meat and dairy was considered as positive and taking a higher score is associated with the higher consumption of such foods and items including fat and sugar are considered as negative and their higher score represents their lower consumption. The frequency of food consumption was calculated in both groups. There were 16 items for positive diet and 12 items for negative diet. Total score was measured by considering from 4 points for daily to zero for never regarding the positive items and vice versa for the negative items. The score of zero to 33 indicated poor nutritional status, the score of 34 to 66 represented a moderately appropriate nutritional status and the score of 67 to 100 represented an appropriate nutritional status. In fact, the higher score reflected better nutritional status. Unhealthy behavior questionnaire was a researcher-made questionnaire with 8 items and 22 points. The scores were converted to 0-100, where 0-33, 34-66 and 67-100 respectively showed the low, moderate and the high risk behaviors. Content validity was used to validate this questionnaire, and retest was used to determine its reliability. Pearson's correlation coefficient using test-retest method within a 10 day interval was equal to 0.82 .

Questionnaires were completed by a trained researcher through interviews. Content validity was used for validity, and test-retest was used for reliability of diet, and unhealthy behaviors questionnaires. Pearson's correlation coefficient was 0.82 for diet questionnaire, which its validity and reliability have been confirmed in various studies (24-26). Pearson's correlation coefficient was 0.9 for unhealthy behaviors questionnaire. Data were analyzed with SPSS version 17 using T-test, Chi-square test and Mann-Whitney-U test. The t-test was used to compare age, weight, body mass index, menarche age, mean scores of type of feeding, mean scores of different groups of food on the food pyramid and mean scores of type of food between the 2 groups. Mann-Whitney-U test was used to compare husband's education, education, occupation, husband's occupation, monthly income and the Chisquare test was used to compare marital status between the two groups and an $\alpha=0.05$ was considered as the level of statistical significance.

\section{Results}

In this study, 116 women with BC and 116 healthy women participated. Table 1, demonstrate demographics of the subjects. There was no difference between the two groups in terms of age, weight, BMI, menarche age. The results of the current study indicated a statistically significant difference in terms of nutritional status between patients with and without $\mathrm{BC}(\mathrm{P}<0.001)$ (Table 2$)$. The nutrition score was not less than 33 in either of the groups; it was $34-66$ in $62 \%$ of people with cancer and in $34.5 \%$ of non-cancer individuals and $67-100$ in $38 \%$ of patients with cancer and in $65.5 \%$ of non-cancer individuals. The mean nutritional score was 56.14 in patients with cancer 
Ataollahi M et al.

Table 1. Demographic Characteristics of the Two Groups ${ }^{\text {a }}$

\begin{tabular}{|c|c|c|c|}
\hline & $\begin{array}{l}\text { Breast } \\
\text { Cancer }\end{array}$ & $\begin{array}{c}\text { Non Breast } \\
\text { Cancer }\end{array}$ & PValue \\
\hline Age, $y$ & $50.07 \pm 14.92$ & $50.12 \pm 6.39$ & 0.8 \\
\hline Weight, kg & $69.65 \pm 14.05$ & $63.60 \pm 9.11$ & 0.2 \\
\hline BMI, $\mathrm{kg} / \mathrm{m}^{2}$ & $26.08 \pm 4.84$ & $24.52 \pm 4.23$ & 0.4 \\
\hline Menarche age, y & $13.77 \pm 2.55$ & $13.8 \pm 1.56$ & 0.8 \\
\hline Education & & & 0.35 \\
\hline > High school & 39.5 & 62 & \\
\hline$<$ High school & 60.5 & 38 & \\
\hline Husband's education & & & 0.09 \\
\hline > High school & 34.5 & 18.5 & \\
\hline > High school & 65.5 & 81.5 & \\
\hline Housewife & 67.25 & 77.5 & 0.15 \\
\hline Self-employed Husband & 34.5 & 32.8 & 0.62 \\
\hline Monthly income, Rials & & & 0.21 \\
\hline$<6,000,000$ & 65.5 & 60.5 & \\
\hline$>6,000,000$ & 19.5 & 22 & \\
\hline Marital status & & & 0.65 \\
\hline Married & 53.4 & 58.6 & \\
\hline single & 46.6 & 41.4 & \\
\hline
\end{tabular}

$\mathrm{a}$ Data are presents as mean \pm SD or percent.

Table 2. Comparison of Mean Scores of Feeding Type in the Two Groups a,b

\begin{tabular}{lcc}
\hline Score & $\begin{array}{c}\text { Breast Cancer } \\
(\mathbf{n = 1 1 6})\end{array}$ & $\begin{array}{c}\text { Non Breast Cancer } \\
(\mathbf{n = 1 1 6})\end{array}$ \\
\hline $\mathbf{0 - 3 3}$ & 0 & 0 \\
$\mathbf{3 4 - 6 6}$ & 78.2 & 34.5 \\
$\mathbf{6 7 - 1 0 0}$ & 21.8 & 65.5 \\
Mean \pm SD & $56.14 \pm 7.55$ & $66.25 \pm 9.2$ \\
\hline $\begin{array}{l}\text { a Data are presented as Percent. } \\
\text { b P Value using t-test }<0.001 .\end{array}$ & & \\
& &
\end{tabular}

and 66.25 in healthy individuals. The findings indicate more appropriate nutrition in healthy people than in those with BC. The frequency of consumption of food groups based on the food pyramid is shown in Table 3. In this regard, there is a statistically significant difference between the two groups. Consumption of fruits, vegetables, meat and dairy was significantly higher in healthy people than in patients with cancer, but consumption of cereals, fat and pastry was higher in people with cancer than in healthy people. The frequency of food consumption in both groups is shown in Table 4 . There was a statistically significant difference between the two groups in terms of the type of food. In terms of food, consumption of whole wheat bread, fish, cheese, yogurt and nuts was higher in healthy people than in patients with BC, but consumption of fast food, white sauce, rice and liquid and solid frying oil was higher in patients with cancer than in healthy people.
Table 3. Comparison of Mean Scores of Different Groups of Food on the Food Pyramid in the Two Groups ${ }^{a}$

\begin{tabular}{lccc}
\hline Food Groups Breast Cancer & $\begin{array}{c}\text { Non Breast Cancer } \\
(\mathbf{n}=\mathbf{1 1 6})\end{array}$ & P Value \\
\hline Cereals & $11.15 \pm 1.19$ & $10.12 \pm 1.21$ & 0.01 \\
Fruits & $3.28 \pm 0.515$ & $3.56 \pm 0.455$ & 0.008 \\
Vegetables & $2.45 \pm 0.554$ & $3.37 \pm 0.793$ & $<0.001$ \\
Meat & $9.52 \pm 1.02$ & $10.75 \pm 1.09$ & $<0.001$ \\
Dairy & $8.25 \pm 1.22$ & $10.04 \pm 1.03$ & $<0.001$ \\
Fats and & $1.07 \pm 1.08$ & $2.06 \pm 1.08$ & $<0.001$ \\
pastry & & & \\
\hline a & & &
\end{tabular}

${ }^{\mathrm{a}}$ Data are presented as mean $\pm \mathrm{SD}$.

Table 4. Comparison of Mean Scores of Type of Food in the Two Groups ${ }^{\mathrm{a}}$

\begin{tabular}{lccc}
\hline Type of Food & $\begin{array}{c}\text { Breast Cancer } \\
(\mathbf{n}=\mathbf{1 1 6})\end{array}$ & $\begin{array}{c}\text { Non Breast Cancer } \\
(\mathbf{n}=\mathbf{1 1 6})\end{array}$ & \\
\hline Bread & $3.78 \pm 0.640$ & $3.43 \pm 0.620$ & 0.008 \\
\hline $\begin{array}{l}\text { Wholemeal } \\
\text { bread }\end{array}$ & $2.05 \pm 1.76$ & $2.82 \pm 1.21$ & 0.008 \\
White sauce & $1.28 \pm 1.12$ & $2.75 \pm 1.81$ & 0.001 \\
\hline Fast foods & $1.43 \pm 0.89$ & $2.42 \pm 1.108$ & 0.007 \\
Fish & $1.52 \pm 0.907$ & $2.29 \pm 0.913$ & 0.001 \\
Cheese & $1.42 \pm 0.613$ & $3.95 \pm 0.928$ & 0.001 \\
Yogurt & $2.17 \pm 0.514$ & $3.18 \pm 0.802$ & 0.001 \\
Brains & $2.201 \pm 1.203$ & $3.407 \pm 0.928$ & 0.001 \\
\hline $\begin{array}{l}\text { Liquid and } \\
\text { solid frying oils }\end{array}$ & $10.04 \pm 1.03$ & $3.12 \pm 1.82$ & 0.001 \\
\hline Dat & & &
\end{tabular}

$\mathrm{a}$ Data are presented as mean $\pm \mathrm{SD}$.

b t-test.

\section{Discussion}

The analysis of the data showed a significant relationship between BC and inappropriate $\operatorname{diet}(\mathrm{P}<0.001)$ and the findings indicate more inappropriate nutrition in $\mathrm{BC}$ than in those with healthy people. Also the results of this study showed insignificant differences in terms of diet, food groups and the type of food used among $\mathrm{BC}$ patients and non- $\mathrm{BC}$ individuals $(\mathrm{P}<0.001)$, which represents the effect of diet on $\mathrm{BC}$, but no relationship was observed between BC and unhealthy behaviors. The results of previous studies also show the relationship between diet and BC (24), which is consistent with our findings. In our study, consumption of fruits and vegetables was higher in healthy people than in patients with cancer. The results of previous studies indicate that elevated fruit and vegetable consumption reduces BC risk $(25,26)$. Fruits and vegetables have been reported to reduce the rate of breast cancer. The survival rate is higher in people who use more fruits and vegetables. 
Also, survival of people who use fruits and vegetables five or more times during a week is higher than those who eat fruits less than five times (21, 25, 27-29). Vegetable consumption decreased $6 \%$ of the breast cancer risk and fruit consumption was associated with $12 \%$ decrease (30). The direct relationship between receiving folate and reduction in $\mathrm{BC}$ has been reported. This reduction was higher in women with a high intake of vitamin B6 and vitamin B12 (31). Also receiving high levels of folate has a protective role against BC (32) and may be associated with lower risk of $\mathrm{BC}$ among moderate to high alcohol-drinkers (31). Folate is one of the B vitamins that exists in many food sources especially in dark green vegetables, fruits, liver, potato, dairy, bread and cereals (32, 33) and among food sources, fruits and vegetables are rich sources of folate (30). The relationship of folate intake, and fruit and vegetable consumption with reduction in BC risk has been raised. This may be attributed to the effect of folate in vegetables $(21,34,35)$. In the current research, the rate of meat and dairy consumption was higher in healthy people than in patients with cancer. Fung et al. found that meat and dairy consumption in premenopausal ages is associated with increased risk of BC (30), which is contrary to our findings. Also the direct relationship between receiving carbohydrate and BC has been suggested (36), which is consistent with the current study. However, in some studies, an inverse relationship was expressed between them $(37,38)$, which is contrary to the present study and in some other studies no relationship was found between them $(39,40)$. In some studies on protein intake, a direct significant relationship is mentioned between protein intake and increased risk of $\mathrm{BC}(36,40)$, which is in contrast to our findings and some other studies have found no relationship between protein intake and increased risk of BC (41). In our study, fish consumption was higher in healthy individuals than patients with cancer. Diet including chicken, fish and turkey is associated with a lower risk of breast cancer (30), which was consistent with our findings. Our findings indicated that patients with $\mathrm{BC}$ use more liquid and solid frying oils. The reports on this issue are contradictory. In some studies, there is a very close relationship between fat intake and increased risk of breast cancer $(42,43)$, which is consistent with our study. But in some studies, there were no relationship between them (38), which is contrary to our findings. The rate of cereal consumption was higher in healthy individuals than in patients with cancer. However, some studies have raised that whole-grain intake is associated with a lower risk of BC (30), which is contrary to our findings. Increased alcohol consumption increases BC (44). Alcohol consumption is one of the major risk factors for BC. Smoking increases the risk of breast cancer. Various studies conducted showed that the incidence of $\mathrm{BC}$ in smokers is 4.6 times higher and this rate is 3.2 times higher in women who are exposed to cigarette smoke for two hours a day for 25 years (14).
The published results from these studies have generally suggested that women who regularly consume alcohol may be at a slightly increased risk of the disease, but the findings reported for tobacco are inconsistent. Alcohol and tobacco consumption are known to be associated with another, and published results have not always allowed adequately for possible confounding between these exposures (9). There is potential for confounding between the possible effects of alcohol and of tobacco on BC, as drinking and smoking are closely associated, one with another (45-48). Given the high prevalence of breast cancer and its increasing trend, prevention and reduction of mortality due to breast cancer is very important. According to the results of this study, women with $\mathrm{BC}$ have more improper diet than healthy individuals; thus, diet is likely to be one of the important factors affecting BC and modifying diet can prevent BC or reduce its mortality. Therefore, emphasis on modified diet is recommended as a non-medical option for prevention of $\mathrm{BC}$.

\subsection{Strong Points}

Considering high prevalence of $\mathrm{BC}$ and the direct relationship between nutritional factors and BC, modifying diet is recommended. Training and giving awareness is necessary for women and girls, especially about appropriate diet and unhealthy behavior.

\subsection{Limitations}

This study has been done on women referred to MRI center that - maybe - cannot represent all of the women and the results cannot be generalized to all the women of the child-bearing age and dietary assessment is mostly based on self-reports.

\section{Acknowledgements}

The respected officials of the Mahdieh MRI center of Hamadan and all participants, who cooperated with us for executing this research, are highly appreciated.

\section{Authors' Contributions}

Maryam Atallahi participated in design and data collection, and writing the manuscript Zahra Masomi helped in design and writing the manuscript Sedigheh Sedighi helped in statistical analysis and writing the manuscript.

\section{References}

1. DeSantis C, Siegel R, Bandi P, Jemal A. Breast cancer statistics, 2011. CA Cancer JClin. 2011;61(6):409-18.

2. Siegel R, Naishadham D, Jemal A. Cancer statistics, 2012. CA Cancer J Clin. 2012;62(1):10-29.

3. Jassem J, Buchanan M, Janicke F, Baum M, Cataliotti L, Kyriakides S, et al. The Hamburg statement: the partnership driving the European agenda on breast cancer. Eur J Cancer. 2004;40(12):1810-1.

4. Okobia M, Bunker C, Zmuda J, Kammerer C, Vogel V, Uche E, et al Case-control study of risk factors for breast cancer in Nigerian women. Int J Cancer. 2006;119(9):2179-85. 
5. Michels KB, Mohllajee AP, Roset-Bahmanyar E, Beehler GP, Moysich KB. Diet and breast cancer: a review of the prospective observational studies. Cancer. 2007;109(12 Suppl):2712-49.

6. Pisani P, Bray F, Parkin DM. Estimates of the world-wide prevalence of cancer for 25 sites in the adult population. Int J Cancer. 2002;97(1):72-81.

7. Romieu I. Diet and breast cancer. Salud Publica Mex. 2011;53(5):430-9.

8. Chia KS, Reilly M, Tan CS, Lee J, Pawitan Y, Adami HO, et al. Profound changes in breast cancer incidence may reflect changes into a Westernized lifestyle: a comparative population-based study in Singapore and Sweden. Int J Cancer. 2005;113(2):302-6.

9. Stark A, Kleer CG, Martin I, Awuah B, Nsiah-Asare A, Takyi V, et al. African ancestry and higher prevalence of triple-negative breast cancer: findings from an international study. Cancer. 2010;116(21):4926-32.

10. Farooq S, Coleman MP. Breast cancer survival in South Asian women in England and Wales. J Epidemiol Community Health. 2005;59(5):402-6.

11. Harrison S, Hayes SC, Newman B. Level of physical activity and characteristics associated with change following breast cancer diagnosis and treatment. Psychooncology. 2009;18(4):387-94.

12. Hamilton AS, Mack TM. Puberty and genetic susceptibility to breast cancer in a case-control study in twins. $N$ Engl J Med. 2003;348(23):2313-22.

13. Jemal A, Siegel R, Ward E, Hao Y, Xu J, Murray T, et al. Cancer statistics, 2008. CA Cancer J Clin. 2008;58(2):71-96.

14. Khazaee-Pool M, Montazeri A, Majlessi F, Rahimi Foroushani A Nedjat S, Shojaeizadeh D. Breast cancer-preventive behaviors: exploring Iranian women's experiences. BMC Womens Health. 2014;14(1):41.

15. Cottet V, Touvier M, Fournier A, Touillaud MS, Lafay L, ClavelChapelon F, et al. Postmenopausal breast cancer risk and dietary patterns in the E3N-EPIC prospective cohort study. Am J Epidemiol. 2009;170(10):1257-67.

16. Key TJ, Allen NE, Spencer EA, Travis RC. Nutrition and breast cancer. Breast. 2003;12(6):412-6.

17. Anand P, Kunnumakkara AB, Sundaram C, Harikumar KB, Tharakan ST, Lai OS, et al. Cancer is a preventable disease that requires major lifestyle changes. Pharm Res. 2008;25(9):2097-116.

18. Fung TT, Hu FB, Holmes MD, Rosner BA, Hunter DJ, Colditz GA, et al. Dietary patterns and the risk of postmenopausal breast cancer. Int J Cancer. 2005;116(1):116-21.

19. Escrich E, Moral R, Solanas M. Olive oil, an essential component of the Mediterranean diet, and breast cancer. Public Health Nutr. 2011;14(12A):2323-32.

20. Stoll BA. Western nutrition and the insulin resistance syndrome: a link to breast cancer. Eur J Clin Nutr.1999;53(2):83-7.

21. Larsson SC, Giovannucci E, Wolk A. Folate and risk of breast cancer: a meta-analysis. J Natl Cancer Inst. 2007;99(1):64-76.

22. Kaaks R, Rinaldi S, Key TJ, Berrino F, Peeters PH, Biessy C, et al Postmenopausal serum androgens, oestrogens and breast cancer risk: the European prospective investigation into cancer and nutrition. Endocr Relat Cancer. 2005;12(4):1071-82.

23. Curi DD, Fonseca AM, Marcondes JA, Almeida JA, Bagnoli VR, Soares JM, Jr, et al. Metformin versus lifestyle changes in treating women with polycystic ovary syndrome. Gynecol Endocrinol. 2012;28(3):182-5.

24. Key TJ, Sharp GB, Appleby PN, Beral V, Goodman MT, Soda M, et al. Soya foods and breast cancer risk: a prospective study in Hiroshima and Nagasaki, Japan. BrJ Cancer. 1999;81(7):1248-56.

25. Smith-Warner SA, Spiegelman D, Yaun SS, Adami HO, Beeson WL, van den Brandt PA, et al. Intake of fruits and vegetables and risk of breast cancer: a pooled analysis of cohort studies. JAMA. 2001;285(6):769-76.

26. van Gils $\mathrm{CH}$, Peeters PH, Bueno-de-Mesquita HB, Boshuizen HC, Lahmann PH, Clavel-Chapelon F, et al. Consumption of vegetables and fruits and risk of breast cancer. JAMA. 2005; 293(2):183-93.

27. Irwin ML, Smith AW, McTiernan A, Ballard-Barbash R, Cronin K, Gilliland FD, et al. Influence of pre- and postdiagnosis physical activity on mortality in breast cancer survivors: the health, eating, activity, and lifestyle study. J Clin Oncol. 2008;26(24):3958-64.

28. Djuric Z, Depper JB, Uhley V, Smith D, Lababidi S, Martino S et al. Oxidative DNA Damage Levels in Blood from Women at High Risk for Breast Cancer are Associated with Dietary intakes of Meats, Vegetables, and Fruits. Americ Dietetic Association J. 1998;98(5):524-8.

29. Boyd NF, Stone J, Vogt KN, Connelly BS, Martin LJ, Minkin S. Dietary fat and breast cancer risk revisited: a meta-analysis of the published literature. BrJCancer. 2003;89(9):1672-85.

30. Fung TT, Hu FB, McCullough ML, Newby PK, Willett WC, Holmes MD. Diet quality is associated with the risk of estrogen receptor-negative breast cancer in postmenopausal women. J Nutr. 2006;136(2):466-72.

31. Zhang SM, Willett WC, Selhub J, Hunter DJ, Giovannucci EL, Holmes MD, et al. Plasma folate, vitamin B6, vitamin B12, homocysteine, and risk of breast cancer. $J$ Natl Cancer Inst. 2003;95(5):373-80.

32. Lajous M, Romieu I, Sabia S, Boutron-Ruault MC, Clavel-Chapelon F. Folate, vitamin B12 and postmenopausal breast cancer in a prospective study of French women. Cancer Causes Control. 2006;17(9):1209-13.

33. Lajous M, Lazcano-Ponce E, Hernandez-Avila M, Willett W, Romieu I. Folate, vitamin $\mathrm{B}(6)$, and vitamin $\mathrm{B}(12)$ intake and the risk of breast cancer among Mexican women. Cancer Epidemiol Biomarkers Prev. 2006;15(3):443-8.

34. Baglietto L, English DR, Gertig DM, Hopper JL, Giles GG. Does dietary folate intake modify effect of alcohol consumption on breast cancer risk? Prospective cohort study. BMJ. 2005;331(7520):807.

35. Ishihara J, Sobue T, Yamamoto S, Sasaki S, Tsugane S, Jphc Study Group . Demographics, lifestyles, health characteristics, and dietary intake among dietary supplement users in Japan. Int J Epidemiol. 2003;32(4):546-53.

36. Romieu I, Lazcano-Ponce E, Sanchez-Zamorano LM, Willett W, Hernandez-Avila M. Carbohydrates and the risk of breast cancer among Mexican women. Cancer Epidemiol Biomarkers Prev. 2004;13(8):1283-9.

37. Sieri S, Krogh V, Muti P, Micheli A, Pala V, Crosignani P, et al. Fat and protein intake and subsequent breast cancer risk in postmenopausal women. Nutr Cancer. 2002;42(1):10-7.

38. Wakai K, Dillon DS, Ohno Y, Prihartono J, Budiningsih S, Ramli $\mathrm{M}$, et al. Fat intake and breast cancer risk in an area where fat intake is low: a case-control study in Indonesia. Int J Epidemiol. 2000;29(1):20-8.

39. Holmes MD, Liu S, Hankinson SE, Colditz GA, Hunter DJ, Willett WC. Dietary carbohydrates, fiber, and breast cancer risk. Am JEpidemiol. 2004;159(8):732-9.

40. Nielsen TG, Olsen A, Christensen J, Overvad K, Tjonneland A. Dietary carbohydrate intake is not associated with the breast cancer incidence rate ratio in postmenopausal Danish women. J Nutr. 2005;135(1):124-8.

41. Howe GR, Hirohata T, Hislop TG, Iscovich JM, Yuan JM, Katsouyanni K, et al. Dietary factors and risk of breast cancer: combined analysis of 12 case-control studies. J Natl Cancer Inst. 1990;82(7):561-9.

42. Cho E, Spiegelman D, Hunter DJ, Chen WY, Stampfer MJ, Colditz GA, et al. Premenopausal fat intake and risk of breast cancer. $J$ Natl Cancer Inst. 2003;95(14):1079-85.

43. Saadatian-Elahi M, Norat T, Goudable J, Riboli E. Biomarkers of dietary fatty acid intake and the risk of breast cancer: a metaanalysis. Int J Cancer. 2004;111(4):584-91.

44. Feigelson HS, Jonas CR, Robertson AS, McCullough ML, Thun MJ, Calle EE. Alcohol, folate, methionine, and risk of incident breast cancer in the American Cancer Society Cancer Prevention Study II Nutrition Cohort. Cancer Epidemiol Biomarkers Prev. 2003;12(2):161-4.

45. Wiseman M. The second World Cancer Research Fund/American Institute for Cancer Research expert report. Food, nutrition, physical activity, and the prevention of cancer: a global perspective. Proc Nutr Soc. 2008;67(3):253-6. 


\section{Ataollahi Met al.}

46. Smith-Warner SA, Spiegelman D, Yaun SS, van den Brandt PA, Folsom AR, Goldbohm RA, et al. Alcohol and breast cancer in women: a pooled analysis of cohort studies. JAMA. 1998;279(7):535-40.

47. Singletary KW, Gapstur SM. Alcohol and Breast Cancer. Jama. 2001;286(17):2143.
48. Stolzenberg-Solomon RZ, Chang SC, Leitzmann MF, Johnson KA, Johnson C, Buys SS, et al. Folate intake, alcohol use, and postmenopausal breast cancer risk in the Prostate, Lung, Colorectal, and Ovarian Cancer Screening Trial. Am J Clin Nutr. 2006;83(4):895-904 